\title{
International Bureau of Weights and Measures
}

National Cancer Institute

\section{Source}

National Cancer Institute. International Bureau of Weights and Measures. NCI

Thesaurus. Code C42542.

International Bureau of Weights and Measures (BIPM, for Bureau International des Poids et Mesures) is the agency which was given authority by diplomatic treaty the Convention of the Metre to maintain the International System of Units and to act in matters of world metrology, particularly concerning the demand for measurement standards of ever increasing accuracy, range and diversity, and the need to demonstrate equivalence between national measurement standards. 